\title{
Uji Efek Antioksidan Formulasi Nanoemulsi Ekstrak Etanol Daun Parang Romang (Boehmeria virgata)
}

\author{
Magfirah \\ Sekolah Tinggi Ilmu Farmasi Pelita Mas Palu (STIFA-PM) Palu \\ magfiralukman@gmail.com
}

\begin{abstract}
ABSTRAK
Upaya menangkal terjadinya penyakit degeneratif akibat terakumulasi radikal bebas, salah satunya adalah pemanfaatan daun parang romang (Boehmeria virgata) yang memiliki potensi kandungan antioksidan yang diformulasikan dalam sediaan nanoemulsi. Tujuan dari penelitian ini mengetahui aktivitas antioksidan formulasi nanoemulsi ekstrak etanol daun parang romang. Daun Parang romang diekstraksi secara maserasi.selanjutnya diformulasi menjadi sediaan nanoemulsi dengan metode simple lattice design. Spektrofotometer UV-Vis digunakan untuk mengukur aktivitas antioksidan.. Hasil penelitian menunjukkan aktivitas antioksidan dengan metode DPPH pembanding kuersetin dan formulasi nanaoemulsi masing-masing diperoleh nilai $\mathrm{IC}_{50}$ yaitu $19,82 \mu \mathrm{g} / \mathrm{mL}$ dan $96,36 \mu \mathrm{g} / \mathrm{ml}$. Hal ini menunjukkan bahwa formulasi nanoemulsi ekstrak daun parang romang memiliki aktivitas antioksidan yang kuat.
\end{abstract}

Kata Kunci : Daun Parang romang, Nanoemulsi, Antioksidan, DPPH.

\section{PENDAHULUAN}

Radikal bebas adalah atom atau molekul yang sangat reaktif sebab memiliki satu atau lebih electron yang tidak berpasangan sehingga molekul radikal bebas akan bereaksi dengan molekul disekitarnya untuk memperoleh pasangan elektron. Reaksi ini akan berlangsung terus menerus dalam tubuh dan jika tidak dihentikan akan menyebabkan berbagai penyakit degenerative seperti kanker karena itu diperlukan antioksidan yang mampu menangkap radikal bebas (Martinus and Verawati 2016)
Senyawa antioksidan banyak ditemukan pada tumbuhan, baik pada bunga, daun maupun buah. Tumbuhan yang mengandung senyawa bioaktif seperti terpenoid, alkaloid, dan flavonoid adalah bahan baku yang digunakan sebagai antioksidan alami.(Sari Nirmala 2016). Salah satu tanaman yang digunakan secara empris masyarakat Makassar adalah parang romang (Boehmeria virgata) sebagai anti tumor(Lukman et al. 2015). Penelitian lain menunjukkan bahwa parang romang dapat menurunkan kadar glukosa darah dan kolesterol pada hewan uji (Rusdi et al. 2017). selain itu parang romang juga 
memiliki aktivitas antibakteri (Arifuddin 2014).

Parang romang banyak ditemukan di daerah pegunungan seperti Malino, Enrekang, Sinjai, Maros dan mengandung senyawa golongan alkaloid, terpenoid, fenolik, dan flavonoid dan (Rusdi 2012). Ekstrak etanol parang romang memiliki nilai $\mathrm{IC}_{50} \quad 9,40 \quad \mu \mathrm{g} / \mathrm{ml}$ (Magfirah and Manggau 2018).

Parang romang memiliki aktivitas antioksidan yang kuat. Saat ini, penemuan obat baru terutama obat dengan kelarutan air yang rendah, sehingga memberikan gambaran bioavailabilitas yang rendah termaksud ekstrak. salah satu cara yang dapat digunakan untuk mengatasi hal tersebut adalah pembuatan nanoemulsi yaitu pengembangan formulasi SNEDDS ekstrak etanol daun parang romang yang dapat meningkatkan kelarutan ekstrak parang romang sehingga menghasilkan bioavaibilitas yang tinggi(Magfirah and Utami 2021b).

Metode perendaman radikal bebas DPPH dapat digunakan untuk mengukur aktivitas antioksidan nanoemulsi daun Parang Romang untuk memperoleh nilai IC50. Molekul DPPH merupakan senyawa radikal bebas stabil dengan warna ungu dan absorbansi yang kuat pada panjang gelombang $\pm 520 \mathrm{~nm}$ (Rusdi and Hasan 2014). Penelitian ini bertujuan untuk menetapkan aktivitas antioxidant activity formula nanoemulsi daun parang romang (Boehmeria virgata)

\section{METODE PENELITIAN}

\section{Tempat dan Waktu Penelitian}

Penelitian dilakukan pada Bulan Januari - Maret 2021 di Laboratorium Fitokimia Farmakognosi dan laboratorium Instrument STIFA Pelita Mas Palu.

\section{Alat dan Bahan}

Alat yang digunakan: Alat-alat gelas, Mortir dan stamper, Magnetic stirrer, Penangas air, Pipet mikro, Rotary vacum evaporator, Timbangan gram dan Timbangan analitik, spektrofotometri uv-vis.

Bahan yang digunakan : Etanol P.a, DPPH, ekstrak etanol daun parang romang, Kuersetin, kapas, alumunium foil.

\section{Prosedur Penelitian}

\section{Ekstraksi}

Sebanyak 800 g serbuk daun tumbuhan parang romang) dimaserasi dengan etanol 8 L selama 5 hari, kemudian campuran sampel 
dan pelarut ini disaring hingga diperoleh ekstrak kemudain dipekatkan dengan rotavapor hungga menjadi ekstrak etanol pekat. kemudian dihitung \% rendeman ekstrak (Magfirah and Utami,2021).

\section{Pembuatan Sediaan Nanoemulsi}

Ekstrak etanol daun parang romang sebanyak $100 \quad \mathrm{mg}$ ditambahkan ke dalam $100 \mathrm{~mL}$ komponen pembawa (minyak zaitun, kombinasi tween 20 dan tween 80 , propilen glikol) dengan komposisi optimal sesuai dengan hasil optimasi yang telah dilakukan dengan menggunakan metode simple lattice design. Kemudian dihomogenkan dengan hotplate magnetic stirrer pada suhu $45^{\circ} \mathrm{C}$ selama 2 jam. Hasil pencampuran didiamkan selama 24 jam pada suhu ruangan. Formula yang tetap homogen (tidak memisah) merupakan formula yang terpilih (Magfirah and Utami, 2021)

\section{Pembuatan Larutan DPPH 0,4 mM}

$$
\text { Sebanyak } \pm 16 \mathrm{mg} \text { DPPH }
$$
ditimbang kemudian kemudian dilarutkan pada pelarut etanol p.a, 15 ml, lalu dimasukan pada labu ukur 50 $\mathrm{ml}$, volumenya di cukupkan sampai pada tanda batas sehingga diperoleh larutan DPPH $0,4 \mathrm{mM}$ (Martinus and Verawati. 2016)
Penentuan Panjang gelombang maksimum DPPH

Etanol P.a 3,5 ml dimasukan kedalam tabung reaksi tambahkan DPPH 0,4 mM sebanyak 1,5 ml lalu diinkubasi pada suhu $37^{\circ} \mathrm{C}$, selama 10 menit. Kemudian dilakukan pembacaan absorban pada panjang gelombang 500-550 nm (Handayani, Kurniawati, and Abdul Rasyid 2020)

\section{Penentuan Operating Time}

Sebanyak 3,5 mL nanoemulsi ekstrak daun parang romang, ditambahkan larutan DPPH 0,4 mM sebanyak 1,5 ml lalu diinkubasi pada suhu $37{ }^{0} \mathrm{C}$. kemudian dibaca absorban sampel pada rentang waktu 5-50 menit dengan interval 5 menit sampel diukur pada gelombang maksimum (Rastuti and Purwati 2012)

Pembuatan Larutan dan Uji aktivitas Antioksidan pembanding kuersetin

Sebanyak $10 \quad \mathrm{mg}$ kuersetin dilarutkan dalam etanol $96 \%$ lalu dimasukan ke labu tentuukur $10 \mathrm{ml}$ dicukupkan hingga tanda batas. selanjutnya dibuat pengenceran dibuat pengenceran seri konsentrasi 5, 10, 15, dan 20 ppm darimasingmasing seri konsentrasi diambil $1 \mathrm{ml}$, $\begin{array}{llll}\text { ditambahkan } & 2 & \mathrm{ml} & \mathrm{DPPH}\end{array}$ dihomogenkan dengan magnetc stirrer suhu $37^{\circ} \mathrm{C}$ selama 30 menit kemudian 
dibaca absorbannya dipanjang gelombang maksimum (Handayani et al. 2020).

Pembuatan Larutan Uji dan Uji aktivitas Antioksidan Nanoemulsi Ekstrak Etanol Daun Parang Romang

Dipipet larutan sediaan nanoemulsi 0,$5 ; 1 ; 1,5$ dan $2 \mathrm{ml}$ ke labu tentukur $10 \mathrm{ml}$ dan cukupkan dengan aquadest untuk mendapatkan konsentrasi 50; $100 ; 150 ; 200 \quad \mu \mathrm{g} / \mathrm{ml}$. kemudian dipipet sebanyak $1 \mathrm{ml}$ masing-masing konsentrasi sampel ditambahkan $2 \mathrm{ml}$ DPPH dihomogenkan dengan magnetic stirrer pada suhu $37{ }^{\circ} \mathrm{C}$ selama 30 menit kemudian dibaca absorbannya pada panjang gelombang maksimum (Larasati and Jusnita 2020)

\section{Penentuan Persen Inhibisi}

Persen inhibisi dapat di hitung dengan rumus sebagai berikut:

\%inhibisi $=\frac{\mathrm{A} 0-\mathrm{A} 1}{\mathrm{~A} 0} \times 100$ (Larasati and Jusnita 2020)

Keterangan

$\mathrm{A}_{0}=$ absorban kontrol

$\mathrm{A}_{1}=$ absorban sampel

\section{Penentuan Nilai $I_{50}$}

$\mathrm{IC}_{50}$ ditetapkan berdasarkan kurva linear antara konsentrasi larutan nanoemeulsi pada sumbu $\mathrm{x}$ dan $\%$ inhibisi pada sumbu y dari persamaan $y=a+b x$ dapat di hitung nilai

$\mathrm{IC}_{50}=\frac{\mathrm{su}-\mathrm{a}}{r} \quad$ (Handayani et al. 2020).

\section{HASIL DAN PEMBAHASAN}

\section{Ekstraksi}

Berdasarkan hasil ekstraksi yang dilakukan secara maserasi diperoleh persen rendemen ekstrak sebesar $5,31 \%$.

\section{Pembuatan Sediaan Nanoemulsi}

Dari hasil optimasi yang dilakukan terhadap 14 formula hasil dari simple lattice design kombinasi pencampuran minyak zaitun, kombinasi tween 80/20 dan propilenglikol diperoleh 3(tiga) formula yang tidak memisah setelah penyimpanan 24 jam dengan konsentrasi $100 \mathrm{mg}$ ekstrak etanol dalam $70 \mathrm{ml}$ tween80/20, $27 \mathrm{ml}$ propilenglikol dan $3 \mathrm{ml}$ minyak zaitun.

\section{Penentuan panjang gelombang maksimum DPPH}

Panjang gelombang maksimun larutan DPPH yang diperoleh pada penelitian ini yaitu $516 \mathrm{~nm}$, hal ini sesuai dengan rentang panjang gelombang maksimun DPPH 500-520 nm (Rusdi et al. 2014). Untuk selanjutnya panjang gelombang digunakan untuk mengukur absorban pembanding kuersetin dan formulasi 
nanoemulsi ekstrak daun parang romang.

\section{Penentuan Operating time}

Berdasarkan hasil penelitian operating time diperoleh waktu pembacaan absorban yang stabil pada rentan waktu 0-50 menit dengan interval 5 menit diperoleh waktu pembacaan absorban yang stabil adalah 30 menit. Hasil operating time digunakan untuk waktu inkubasi sampel dan pembanding kuersetin Hasil pembacaan operating time sampel dapat dilihat pada tabel 1 .

Tabel 1. Hasil Penentuan Operating Time

\begin{tabular}{|l|l|}
\hline Waktu(menit) & absorban \\
\hline 0 & 0,325 \\
\hline 5 & 0330 \\
\hline 10 & 0,335 \\
\hline 15 & 0,345 \\
\hline 20 & 0,350 \\
\hline 25 & 0,355 \\
\hline 30 & 0,400 \\
\hline
\end{tabular}

\begin{tabular}{|l|l|}
\hline 35 & 0,400 \\
\hline 40 & 0,400 \\
\hline 45 & 0,400 \\
\hline 50 & 0,410 \\
\hline
\end{tabular}

\section{Uji aktivitas antioksidan} pembanding dan sampel uji

Larutan campuran yang akan diukur di inkubasi terlebih dahulu selama 30 menit sehingga (Formulasi nanoemulsi daun parang romang dan DPPH) dan (kuersetin + DPPH) dapat bereaksi secara sempurna. Aktivitas antioksidan pada sampel ditunjukan dengan terjadinya perubahan warna larutan dari warna ungu menjadi kuning(Larasati and Jusnita 2020). Hal ini disebabkan karena adanya donasi atom hidrogen dari senyawa antioksidan ke senyawa radikal DPPH sehingga DPPH tereduksi menjadi DPPH-H (Handayani et al. 2020) Hasil dari pengukuran aktivitas antioksidan dapat dilihat pada tabel 2.

\begin{tabular}{|c|c|c|c|c|c|}
\hline $\begin{array}{l}\text { Sampel } \\
\text { Uji }\end{array}$ & $\begin{array}{l}\text { Konsentrasi } \\
(\mu \mathrm{g} / \mathrm{ml})\end{array}$ & $\begin{array}{l}\text { Absorban } \\
\text { sampel }\end{array}$ & $\begin{array}{l}\text { Absorban } \\
\text { kontrol }\end{array}$ & \%Inhibisi & $\begin{array}{l}\mathrm{IC}_{50} \\
(\mu \mathrm{gml})\end{array}$ \\
\hline \multirow[t]{4}{*}{ Kuersetin } & 5 & 0,676 & \multirow{7}{*}{0,739} & 8,52 & \multirow{4}{*}{19,82} \\
\hline & 10 & 0,565 & & 23,54 & \\
\hline & 15 & 0,462 & & 37,48 & \\
\hline & 20 & 0,371 & & 49,79 & \\
\hline \multirow{3}{*}{$\begin{array}{l}\text { Formulasi } \\
\text { nanoemulsi } \\
\text { daun } \\
\text { parang }\end{array}$} & 50 & 0,456 & & 38,29 & \multirow{3}{*}{97,71} \\
\hline & 100 & 0,361 & & 51,15 & \\
\hline & 150 & 0,282 & & 61,84 & \\
\hline
\end{tabular}




\begin{tabular}{l|l|l|l|l|l|}
\hline romang & 200 & 0,171 & 76,86 & \\
\hline Metode & DPPH & dengan linier
\end{tabular}

spektrofotometri dapat digunakan untuk mengukur aktivitas antioksidan formulasi nanoemulsi daun parang pada panjang gelombang maksimum $516 \mathrm{~nm}$ dan dibandingkan dengan aktivitas antioksidan kuersetin. Besarnya aktivitas antioksidan dilihat dari nilai IC50, yaitu konsentrasi larutan sampel untuk menghambat 50 \% radikal bebas DPPH. Kurva hubungan konsentrasi hasil formulasi nanoemulsi terhadap persentase inhibisi dapat dilihat pada gambar 1

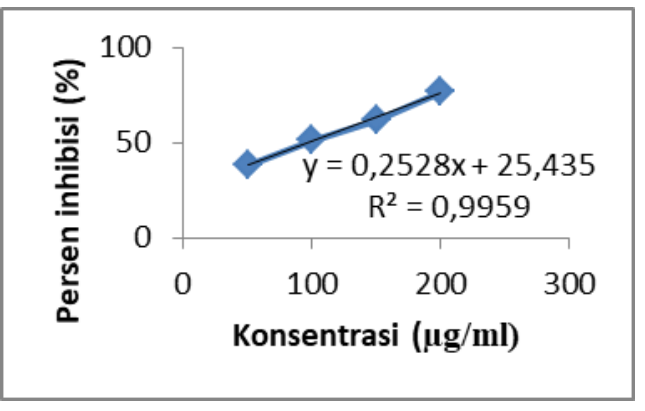

Gambar 1. Kurva baku kuersetin

Adapun sebagai pembanding, dilakukan pengujian aktivitas antioksidan terhadap kuersetin. Kurva Hubungan Konsentrasi kuersetin terhadap Persentase Inhibisi dapat dilihat pada gambar 2 .

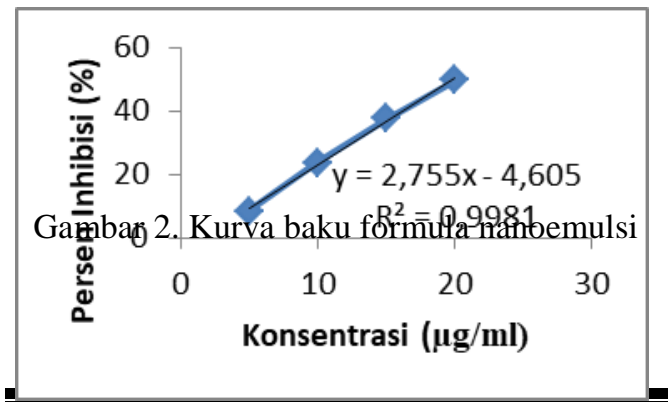


kuersetin merupakan senyawa yang murni (Larasati and Jusnita 2020), (Handayani et al. 2020).

\section{KESIMPULAN}

Berdasarkan hasil penelitian dapat disimpulkan bahwa formulasi nanoemulsi ekstrak daun parang romang berpotensi sebagai antioksidan sedang dengan nilai $\mathrm{IC}_{50}$ sebesar 97,71 $\mu \mathrm{g} / \mathrm{mL}$ sedangkan pembanding kuersetin merupakan antioksidan skuat dengan nilai $\mathrm{IC}_{50} 19,82 \mu \mathrm{g} / \mathrm{mL}$.

\section{UCAPAN TERIMA KASIH}

Penulis mengucapkan terima kasih kepada yayasan Pelita Mas Palu yang telah memberi kesempatan untuk melakukan dan membiayai penelitian ini.

\section{DAFTAR PUSTAKA}

Arifuddin, M. 2014. "Aktivitas Antioksidan, Sitotoksik Dan Penentuan Struktur Senyawa Alkaloid Hasil Isolasi Dari Ekstrak Heksan Daun Parang Romang (Boehmeria Virgata (Forst) Guill)." univiversitas Hasanuddin, Makassar.

Handayani, Selpida, Ida Kurniawati, and Faradiba Abdul Rasyid. 2020. "Uji Aktivitas Antioksidan Ekstrak Daun Karet Kebo (Ficus Elastica) dengan Metode Peredaman Radikal Bebas Dpph (1,1-Diphenyl-2-Picrylhydrazil): Antioxidant Assay of Ficus Elastica Extract Leaf with Dpph Free Radical Scavenging (1,1diphenyl-2-phycrilhydrazyl)."

Jurnal Farmasi Galenika (Galenika Journal of Pharmacy)
(e-Journal) 6(1):141-50. doi: 10.22487/j24428744.2020.v6.i1. 15022 .

Larasati, Shinta Putri, and Nina Jusnita. 2020. "Formulasi Nanoemulsi Ekstrak Kunyit (Curcuma longa L.) Sebagai Antioksidan." Journal of Pharmaceutical And Sciences 3(1):33-41. doi: 10.36490/journaljps.com.v3i1.38.

Lukman, M., Muhammad Rusdi, Mochammad Hatta, Latifa Rahman, Subehan, and A. Manggau Marianti. 2015. "AntiProliferation Activity Of Nanoencapsulated Bioadhesive Vaginal Gel Of Isolated Active Compound (Bvi03) From Boehmeria Virgata (Forst) Guill Leaves Against Human Cancer Cervix Hela Cells." International Journal of Pharma Sciences and Research 6(5):83639.

Magfirah, Magfirah, and Marianti A. Manggau. 2018. "PENGARUH PEMBERIAN EKSTRAK ETANOL DAUN PARANG ROMANG (Boehmeria virgata) SECARA SUBKRONIS ORAL TERHADAP PROFIL HEMATOLOGI TIKUS PUTIH (Rattus Novergicus)." Majalah Farmasi dan Farmakologi 22(1):16. doi: 10.20956/mff.v22i1.5691.

Magfirah, and Indah Kurnia Utami. 2021a. "Formulation and Stability Evaluation Nanoemulsion of Ethanol Extract of Parang Romang Leaf (Boehmeria Virgata)." International Journal of Pharmaceutical Research and Applications 5(2):7.

Magfirah, and Indah Kurnia Utami. 2021b. "Optimization And Characterization Of Formulation 
Self-Nanoemulsifying Drug Delivery System Ethanol Extract Of Parang Romang Leaves (Boehmeria Virgata)." Asian Journal of Pharmaceutical and Clinical Research 207-12. doi:

10.22159/ajpcr.2021.v14i1.3992 2.

Martinus, B. A., and Verawati Verawati. 2016. "Penentuan Kadar Flavonoid Total Dan Aktivitas Antioksidan Dari Ekstrak Daun Bandotan (Ageratum conyzoides L.)." Scientia: Jurnal Farmasi dan Kesehatan 5(1):47. doi: 10.36434/scientia.v5i1.67.

Rastuti, Undri, and Purwati Purwati. 2012. "Uji Aktifitas Antioksidan Ekstrak Daun Kalba(Albizia falcataria) Dengan Metode DPPH(1,1-Difenil-2pikrilhidrazil) dan Identifikasi Senyawa Metabolit Sekunder." Molekul 7(1):33. doi: 10.20884/1.jm.2012.7.1.104.

Rusdi, M., and Tahirah Hasan. 2014. "Perbandingan Metode Ekstraksi Terhadap Kadar Flavonoid Total Dan Aktivitas Antioksidan Batang Boehmeria Virgata Comparison of Extraction Methods on Total Flavonoid Content and Antioxidant Activity of Boehmeria Virgata Stem." 1(1):16-24.
Rusdi, M., Tahirah Hasan, Ardillah, and Evianti. 2014. "Perbandingan Metode Ekstraksi Terhadap Kadar Flavonoid Total Dan Aktivitas Antioksidan Batang Boehmeria Virgata." AdDawaa'Jour.Pharm.Sci 1(1):1624.

Rusdi, Muhammad. 2012. "Isolasi dan karakterisasi senyawa aktif fraksi n-heksan daun parang romang (Boehmeria virgate (Forst) Guill) terhadap sel kanker hela." univiversitas Hasanuddin, Makassar.

Rusdi, Muhammad, Jumratul Jannah, Sitti Fauziah Noer, and Hasyim Bariun. 2017. "Uji Efek Hipoglikemik Ekstrak Etanol Batang Parang Romang (Boehmeria virgata (Forst) Guill)." 5.

Sari Nirmala, Ayu. 2016. "Berbagai Tanaman Rempah Sebagai Sumber Antioksidan Alami." Journal of Islamic Science and Technology 2(2):10.

Sari, Rafika, Ade Ferdinan, Rafika Sari, and Ade Ferdinan. 2018. "Pengujian Aktivitas Antibakteri Sabun Cair Dari Ekstrak Kulit Daun Lidah Buaya." Pharmaceutical Sciences and Research (PSR) 4(3):111-20. doi: 10.7454/PSR.V4I3.3763. 

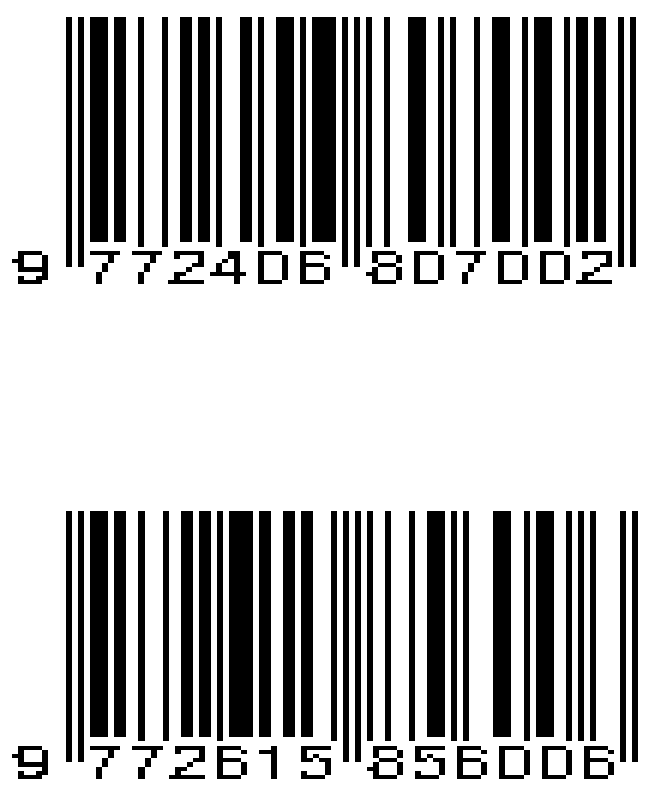